\title{
ICTOPI
}

UDC 94(479.24)

DOI https://doi.org/10.24919/2308-4863/34-5-1

Rakhshanda BAYRAMOVA, orcid.org/0000-0002-1320-4286 Doctoral Student

Institute of History named after A. A. Bakikhanov of the Azerbaijan National Academy of Sciences (Baku,Azerbaijan)rus_rahimli@yahoo.com

\section{IMPLEMENTATION OF THE ACT OF MASSACRE IN GUBA DISTRICT AND ITS CONSEQUENCES}

Between March 30 and April 3, 1918, Armenian armed groups from the Baku Soviet and Dashnaktsutyun attacked Azerbaijanis in Baku and various regions of the Baku province, as well as in Shamakhi, Guba, Khachmaz, Lankaran, Hajigabul, Salyan, Zangazur, Karabakh, Nakhchivan and other areas. committed a massacre against. At various stages of history, Armenian nationalists carried out ethnic cleansing, deportation and genocide against our compatriots in order to realize the mythical idea of a "Greater Armenia".

One of the most terrible tragedies that befell the Azerbaijani people was the massacres committed in March-April 1918 by the Dashnak-Bolshevik armed groups operating under the mandate of the Baku Soviet with special cruelty. After Gelovani left Guba, the situation was relatively stable, so the volunteers from the surrounding areas and Dagestan, who had joined the fight against foreign enemy forces, returned to their homes.

Therefore, in fact, the deployment of a punitive detachment under the leadership of Hamazasp to Guba was somewhat unexpected for the people from Guba and it was not possible to organize a serious resistance. In Guba, as in other parts of the Baku province, the Bolshevik-Dashnak leadership of the Baku Soviet decided to send a second military force, this time an Armenian-only punitive force, under the leadership of Hamazasp, to suppress the national movement and establish its power. According to official sources, as a result of the genocide, about 12,000 Azerbaijanis were killed and tens of thousands were missing. The March events were declared by Heydar Aliyev in March 1998 as the Day of Genocide of Azerbaijanis. In 2013, by the decision of Ilham Aliyev, the Guba Genocide Memorial Complex was established in memory of those killed in the genocide.

During the research, the documents revealing the bloody crimes committed by Armenians against the Muslim population in Guba were analyzed. The article aims to convey to the country and the world community the truth about the crimes committed by Armenian-Bolshevik armed groups against Azerbaijanis 100 years ago.

Key words: Guba, massacre, "Greater Armenia”, Shaumyan, Turkish people.

Рахианда БАЙРАМОВА, orcid.org/0000-0002-1320-4286 докторант

Інституту історії імені А. А. Бакиханова Національної академії наук Азербайджану (Баку, Азербайджан)rus_rahimli@yahoo.com

\section{ЗДІЙСНЕННЯ МАСОВОГО ВБИВСТВА В ГУБИНСЬКОМУ РАЙОНІ ТА ЙОГО НАСЛІДКИ}

У період з 30 березня по 3 квітня 1918 року вірменські збройні групи з Бакинської Ради і Дашнакиутюну напали на азербайджанців у Баку і різних районах Бакинської губернії, а також у Шамах, Губі, Хачмазі, Лянкяране, Гаджігабуле, Сальяні, Зангезуре, Карабасі, Нахчивані. На різних етапах історії вірменські націоналісти проводили етнічні чистки, депортацію і геноцид проти наших співвітчизників, щуоб втілити у життя міфічну ідею «Великої Вірменії».

Однією з найстрашніших трагедій, щзо спіткали азербайджанський народ, були масові вбивства, скоєні у березні-квітні 1918 року дашнаксько-більшовиџькими збройними формуваннями, які діяли за дорученням Бакинської Ради із особливою жорстокістю. Після того, як Геловані покинув Губу, ситуація була відносно стабільною, тому добровольці з околиць і Дагестану, які приєдналися до боротьби з силами іноземного ворога, повернулися до своїх домівок. 
Розміщення карального загону під керівниитвом Хамазаспа в Губі було дещо несподіваним для жителів Губи, тому організувати серйозний опір не вдалося. В Губу, як і в інші частини Бакинської області, більшовицькодамнакське керівництво Бакинської Ради вирішило направити другу військову групу (каральну групу тільки для вірмен) під керівництвом Хамазаспа, щоб придушити наиіональний рух і встановити свою владу. За офіційними даними, в результаті геночиду близько 12 тисяч азербайджанців було вбито, десятки тисяч пропали без вісті. Березневі події були оголошені Гейдаром Алієвим у березні 1998 року Днем геноииду азербайджсаниів. У 2013 роиі рішенням Ільхама Алієва був створений Меморіальний комплекс Губинського геноциду в пам'ять про загиблих під час геноииду.

Під час дослідження були проаналізовані документи, які розкривають криваві злочини, вчинені вірменами проти мусульманського населення в Губі. Мета статті - донести до краӥни і світової громадськості правду про злочини, вчинені вірмено-більшовицькими збройними формуваннями проти азербайджанців 100 років тому.

Ключові слова: Губа, різанина, «Велика Вірменія», Шаумян, туреиький народ.

Introduction, the actuality of the subject. The urgency of the investigation into the genocide in Guba was the distortion of our historical realities in the world, the intensified activity of the Armenian lobby in this case, and, if we are right, our relative backwardness in the information struggle. By keeping these topics on the agenda, we can help spread them around the world and create conditions for historical facts to reach a wider audience.

Purpose and tasks of the research. The main purpose of the research is to convey to the country and the world community the truth about the crimes committed by Armenian-Bolshevik armed groups against Azerbaijanis 100 years ago. The genocide and its remains in Guba are the most obvious evidence of this.

Scientific novelty of research. The scientific novelty of the research was in the approach to the subject from a broader historical context, the use of extensive archival materials, taking into account today's realities in terms of conveying the genocide to the world.

Methods and sources of research. Theoretical and methodological basis of the research is a historical-comparative and descriptive method. The subject of the research is Guba genocide, its consequences, new period literature, contemporary literature samples, researches of Azerbaijan and European scholars.

A review of recent research and publications. When researching the article, scientific articles were used such as "Bloody valley: Guba tragedy of 1918" by M. Malikmammadov; "April-May 1918 Muslim pogroms in documents" by Rustamov-Togidi S. Guba; "Historiography of the problem of Turkish-Muslim genocide in Azerbaijan" by A. Iskandarov; "Armenian Dashnak fascism and Azerbaijan" by A. Erogul etc.

Presentation of the main material. After Gelovani left Guba, the situation was relatively stable, so the volunteers from the surrounding areas and Dagestan, who had joined the fight against foreign enemy forces, returned to their homes. Therefore, in fact, the deployment of a punitive detachment under the leadership of Hamazasp to Guba was somewhat unexpected for the people from Guba and it was not possible to organize a serious resistance. Hearing only Armenian groups approaching the city, local leaders took steps to reorganize their forces, formed groups in a number of villages, including the villages of Khulug, Hil, Yasab and Bedulikola in the Gusar region, and sent representatives to Dagestan for additional assistance.

In Guba, as in other parts of the Baku province, the Bolshevik-Dashnak leadership of the Baku Soviet decided to send a second military force, this time an Armenian-only punitive force, under the leadership of Hamazasp, to suppress the national movement and establish its power. Hamazasp himself did not deny that his group was sent to Guba for punishment: "I am a hero of the Armenian people and its defender. I was sent here by the Soviet government with a punitive order to avenge the Armenians killed two weeks ago. I was sent here not to establish law and order and establish Soviet power, but to avenge the slain Armenians" (ARDA, f. 1061, p. 1, w 96, 35-36).

Hamazasp's words were confirmed in one form or another by most of the witnesses who were brought to meet him in Guba. Witness testimony and sources confirm that Hamazasp was sent to Guba by Shaumyan to punish the Azerbaijani population. After these events, he went to Baku and met with Shaumyan and Japaridze to inform the leadership of the Baku Soviet about the crimes committed by Hamazasp in the district and to clarify the future plans of the Soviet in Guba. Alibayov said that after Shaumyan listened to me, he smiled and said that Muslims and Turks had killed hundreds of thousands of Armenians. Muslims complain that Armenians killed two Muslims in Guba and shed tears (ARDA, f. 1061, p. 1, w. 96, 39).

Gelovani also confirmed that Shaumyan was the initiator of sending a group of Armenians to Guba: "There was not a single Russian in Hamazasp's group, all of them were Armenian Dashnaks. In my opinion, the punitive detachment was sent to Guba at the request of Shaumyan, but the choice of troops depended on the Minister of Defense Korganov" (ARDA, f. 1061, p. 1, w. 96, 119). Before reaching the city of Guba, Armenian gangs began to burn and destroy civilian villages along the way, committing 
massacres. The ruthless Armenians did not spare even the elderly, children and women and destroyed all the Muslims who came before them.

The Armenians kept their echelon in Gizilburun and decided to advance to the local population. According to witnesses, in late April, Hamazasp's group approached Khachmaz, but local forces resisted. However, due to the inequality of forces, after two days of fighting, the punitive detachment was able to make its way to Guba. Hamazasp was at the head of this group. His assistant was Nikolai, and his guide was Harutyun Hayrapetov, a local Armenian nicknamed "Dayirmanchı". According to Alibeyov, the group included about 3000 people, 4 cannons and 8 machine guns (ARDA, f. 1061, p. 1, w 96, 34-39; 232, p. 180).

Various dates are given in the sources regarding the arrival of Gelovani's and Hamazasp's gangs in Guba and the genocide in the district in general. In our opinion, this is due to the use of two calendars in parallel at the same time. Certain inconsistencies in the chronological sequence of events in the sources can also be explained by this.

On May 1, the invaders entered the city from three sides and immediately began killing and looting. On the first day, 715 Muslims, mostly women and children, were killed in the lower part of the city, and the Highway and Bazar streets were destroyed. After the group entered the city, it was divided into four parts and headquarters were set up: the first headquarters was located near Leontyev Park, the second in the courtyard of the Armenian Church, the third in the mountains, near the Muslim cemetery and the fourth, the central headquarters, was on the top of a Jewish settlement. Armenian atrocities continued in the following days, with 1012 civilians killed on the second day. Alibeyov, who came to Hamazasp as a representative of the city population, asked him to allow him to bury the dead, but his request was denied. Although Ha-mazasp appealed to his soldiers to stop the killings and looting, as Alibeyov stressed, this call was far from sincere and was intended to make the soldiers take his words in the opposite way. (ARDA, f. 1061, p. 1, w 96, 35).

Despite repeated appeals, Hamazasp did not allow the bodies of slain Muslims to be collected from the streets and buried. The purpose was clear - to intimidate and frighten the population. Violence, killings and looting lasted for 9 days, and all the property of the city population was looted.

Examination of archival documents revealed that when Hamazasp arrived, an additional force was sent to Guba from Petrovsky. This means that the idea that the Dashnaks engaged in looting in Guba when they arrived in Hamazasp only after Gelovani's departure in early May was 2000 and that the number of gang members was several times higher than this figure. Some authors put the number at 4000 . In our opinion, in fact the number of Dashnaks was higher. Interestingly, the sources state that there were no Druzhina fighters in the Armenian group and that they fired at everyone along the way. "After arriving in Derbent, Ananchenko informed the Revolutionary Committee about the events in Guba", the source said. Meanwhile, Nanashvili sent several Armenian detachments in Petrovsk to Guba. They are firing on everyone along the way. There were no druzhinniks among them (ARPIIISSA, f. 276, p. 2, w 22, 89).

Based on the appeals to the Commission of Emergency Investigation, we can say that Hamazasp's gang looted about 400 houses and burned 2153 houses during their stay in Guba. In total, according to the documents of the Emergency Commission, 2153 houses, 5 caravanserais, 152 warehouses, 166 haystacks, 68 stables, 312 shops, 17 mills, 4 workshops, 4 teahouses and 284 other buildings were looted and set on fire by Dashnaks using mass burning tactics. Hamazasp's group ignored even the religious beliefs of the Muslims, and many mosques and the Holy Qur'an were burned (ARDA, f. 1061, p. 1, w 95, v. 5-8; 232, p. 153-158). According to the commission's documents, 24 mosques were looted and set on fire. Protocols from some districts, including Gusar, did not provide information on the number of mosques burned, suggesting that the number of mosques was higher.

The members of the criminal gang committed atrocities against Muslims that are beyond human comprehension. Witness testimony confirms that Armenian vandals enjoyed the inhumane "experiences" they inflicted on wounded and killed people. The thirsty Dashnak executioners did not give up the corpses of the killed Muslims (ARDA, f. 1061, p. 1, w 96, v. 47-49; 23, p. 187-189). Mashadi Hamdulla Aliyev, a 40-year-old resident of Guba, said he had seen many bodies in the city, about two-thirds of which belonged to children and women. Many women had their breasts cut off and their corpses disfigured with daggers (ARDA, f. 1061, p. 1, w 96, v. 41-43; 232, p. 183-185).

Şahid ifadələri və digər arxiv sənədləri ilə tanışlıq zamanı məlum olur ki, çox hallarda sakinlər kütləvi yığılaraq aparılır, kənar yerlərdə qətlə yetirilirdilər və nəticədə onların basdırıldıqları yerlər gizli qalırdı. Abasbey Balabey oglu Hasanbeyov explains: "In May, on the way from Khach-Maz to Guba. I saw the bodies of Muslims lying in roadside ditches, gnawed by jackals and other animals" (Rustamov-Togidi, 2010: 203-204). 
There are also archival materials about the 300 people killed by Armenians being buried in 51 graves (ARDA, f. 1061, p. 1, w 96, v. 120, 140; 232 , p. 203-204, 229). In our opinion, the reason for the mass burial of these bodies, ie the burial of about 5 corpses in each grave, was that, as mentioned above, the bodies of the killed residents remained on the streets for several days, the terrible situation that arose and 4 days later the believers were finally allowed to be buried, but there were too many human corpses. According to the information provided by the mullahs to the Emergency Investigation Commission, the number of bodies buried in Guba was 2,800 (ARDA, f. 1061, p. 1, w 96, v. 14-16; 232, p. 167-168).

According to some sources, Velunts alone burned 160 houses in Guba, as well as 700 people in the lower part of Guba, and a total of 900 Muslim women, old men and children. Part of Guba was destroyed by his order (September 6, 1919, September 6). The Ittihad newspaper wrote in its September 6 and October 31 issues about Velunts and his "activities" in Guba: "We are ready to prove that this" law enforcement officer "burned 160 houses in Guba and killed 900 people. A Muslim woman, an old man and a child were shot"("İttihad").

According to some authors, more than 3,200 Muslims were killed in the first two days of Hamazasp's stay in Guba in the city and in the villages of the district. If we add that 700 young men with guns were shot on the banks of the Gudyal River, more than 3900 Muslims were killed in just two days (Malikmammadov, 2009: 16). According to some reports, as a result of Hamazasp's atrocities, more than 16000 people were killed in the first five months of 1918 in Guba district (Iskandarov, 2006: 68).

It is very difficult to give an exact figure. Even on the day of Hamazasp's departure, such an Armenian officer attacked the village of Nugadi with several soldiers, first gathering the villagers in front of the mosque, and some of the soldiers began looting their houses, then suddenly opened fire on the residents in front of the mosque. Frightened residents began to flee in all directions. Five people were killed in the shooting.

However, upon learning of the massacre, Churayev sent additional troops to the village to prevent the massacre of civilians and then the Armenians left the village. This was reported by both the witnesses interrogated by the Emergency Commission and later by the former Bolsheviks (Rustamov-Togidi, 2010: 256, 258); (ARPIIISSA, f. 456, p. 18, w 37, v. 164). The Bolsheviks stated in their notes that the bloodthirsty Armenian executioner Hamazasp had killed the Armenians as well as the Muslims. According to the minutes of the memorial evening, Ifraimov, who went to Khachmaz to get help and treat patients, witnessed a terrible scene. Thus, in Khachmaz, the Hamazasp gang brutally slaughtered Armenians and Turks (locals-R.B) leaving Guba. Ifraimov said the bodies were buried in the fraternal cemetery (ARPIIISSA, f. 276, p. 2, w 22, v. 11).

Thus, Hamazasp thirsty for human blood, committed another atrocity against the representatives of his people in order to cover up the atrocities committed by his people, and laid the groundwork for the idea of the future massacre of Armenians by Muslims. It should be noted that the lists submitted to the Emergency Commission of Inquiry rarely provided information about the wounded. It is not possible to give exact figures on the number of injured, as no information about them has been included in the documents.

Documents submitted to the Emergency Commission regarding the damage caused to individual rural communities by the district usually provided a general overview of the damage to families, and in some cases did not provide information on burned houses and other structures.

The Dashnaks destroyed thousands of valuable books on Islam, oriental history and literature. Armenians set fire to Abdurrahim efendi's madrasah in the center of Guba and set fire to about 1300 books. Armenians set fire to Abdurrahim efendi's madrasah in the center of Guba and set fire to about 1300 books. Abdurrahim efendi recalled that "after the expulsion of the Bolsheviks from Guba, I took about 3000 books from the madrasa to my house in Maharramkhur (Maharramkend). But my 1300 books remained in Guba. They were set on fire by Armenians in a madrassa" (Rustamov-Togidi, 2010: 48). According to reports, the Digah mosque had books written in the Albanian and Arabic alphabets about 600-700 years ago. In addition to destroying the books, the Armenians also blew up a tombstone about a kilometer from the village mosque. It was a huge stone with Albanian inscriptions on it (Erogul, 2007: 48). According to the documents of the Emergency Commission of Inquiry, many golden books painted in golden water were burned in the Digah mosque.

Some of the Armenians who took part in the genocide and looting were found guilty by the commission and criminal proceedings were instituted against them. These are Guba residents Hartun Hayrapetov, pimp Javad Arutyunov, Avakov, son of a fisherman Avakov, students of Amirjanov, nephew of merchant Mirza Amirjanov, Mirza Amirjanov, Malikov son of Grigory Vartan, Mirzaja's grandson Harutyun, the owner of the mill, Vartan Avakov, Alexander Mukasyans, Tatevos Yagub oglu, Babajan oglu and Arutyun Karapet oglu, two sons and a nephew (ARDA, f. 1061, p. 1, w 95, v. 9-10; 5, p. 159-161). 
It should be noted that the information about the genocide and certain atrocities committed by the Dashnaks in the Guba region was studied mainly on the basis of documents of the Emergency Investigation Commission. It is true that the commission's documents on the Guba district have certain shortcomings, in particular, certain shortcomings in determining the amount of damage, but it is the only relatively complete set of documents available to revive the events of that period.

In December 1918 Andrei Novatsky, a member of the Ganja District Court, came to Guba with his assistant and began an investigation. The investigation team in connection with the genocide committed in Guba district in April-May 1918 listened to dozens of witnesses for several months, inspected the scene and prepared a 3-volume 451-page collection of documents. Novatsky, a member of the commission of inquiry, presented a report to the chairman of the commission on the destruction of the city of Guba, as well as in the villages of the Guba district, as well as the violence against the civilian population (Rustamov-Togidi, 2010: 89).

The mentioned 3-volume documents included:

1. On the destruction of the city of Guba.

2. On the destruction of Devechi and Mushkur villages.

3. Documents on Gusar, 5th Fathibey and Guba districts.

"Azerbaijan" newspaper (in Russian) wrote in its July 26, 1919 issue that the Emergency Commission had sent a letter to the Ministry of Foreign Affairs regarding the use of force against Muslims in Baku, Guba, Shamakhi, Goychay and other districts during 1918. Materials on current issues were sent. The materials are reviewed for publication and booklets are prepared for publication ("Azerbaijan").

On the basis of the report presented in November 1919, the Extraordinary Commission of Inquiry, signed by the chairman of the commission A. Khasmammadov and other members of the commission, decided to file a criminal case against the perpetrators of the Guba events. Their case was sent to the prosecutor's office of the Baku District Court on January 29, 1920. However, in connection with the de facto recognition of the Azerbaijan People's Republic by the Entente Supreme Council on January 11, 1920, according to the second article of the amnesty law adopted by the Parliament of the Republic on February 9, 1920, this law Prior to its adoption, it was announced that crimes committed on the grounds of international hostility had been terminated and that the investigation of these cases had been suspended.
After the April occupation, on October 10, 1920, the First Investigative Commission of the Guba District Court reconsidered the case and sent him to Guba to terminate the criminal case on the grounds of national hatred under the amnesty law adopted by the APC Parliament on February 9. The accident was sent to the people's court and the case was terminated. In general, the materials and testimonies collected by the Commission of Inquiry prior to April 1920 are significant historical documents exposing the crimes of the Dashnaks and Bolsheviks. Referring to these documents, the ADR government marked March 31, 1919 and 1920 as a day of national mourning.

Alibeyov also stated in his explanation that on the 9th day of the arrival of the bloodthirsty gang, the looted goods were taken by carts from the city to the house of M. J. Bagirov (ARDA, f. 1061, p. 1, w 96, v. 34-39; 5, p. 178-183). This episode was confirmed by M. C Bagirov himself, but in a different way: "After a week of outrageous actions in the Guba district, Hamazasp's gangs gathered all the riches of the district and went to Baku. I managed to get some household items from the owners of the burnt houses by kneeling" (Rustamov-Togidi, 2010: 79).

A number of authors studying this historical period state that Dashnak-Armenian gangs attacked Guba region 3 times (Erogul, 2007: 213). In the first five months of 1918, a large force of Dashnaks, Armenians and Russians hiding under the Bolshevik veil, more than 5,000 soldiers armed from head to toe and more than 300 local Armenian militants began a real war against the civilian population. Therefore, the idea that the Armenian occupiers came to Guba only once, with 2,000 groups, is wrong.

If we take into account the military unit of the Red Army sent from Derbent to Guba on April 26, during 1918 more than 10000 Dashnak-Bolshevik soldiers, armed from head to toe, were sent to Guba (Malikmammadov, 2009: 273). As noted Hamazasp arrived from Baku with a detachment of 2000 people, but later several additional groups of Armenians were sent from Petrovsk to help him (ARPIIISSA, f. 276, p. 2, w 22, v. 89).

Result. Thus, an extensive analysis of the archival materials unequivocally confirms that 1918 The massacres of Guba in 1918 are one of the most tragic pages of the atrocities and genocide committed by the Armenian Dashnaks against the peaceful Azerbaijanis. The massacres committed by Armenian executioners in Guba, as in all other parts of Azerbaijan, were part of the Dashnaks' plans to create a non-Turkish "Greater Armenia" in the future, subjecting the Turkish-Muslim population to genocide in the 
Bayramova R. Implementation of the act of massacre in Guba district and its consequences

South Caucasus. All Armenian forces, regardless of political or party affiliation, were closely involved in the implementation of their plans.

The direct organizers of the Guba massacres were Shaumyan, Korganov the perpetrators were Hamazasp, Volunts and other criminals of Armenian descent. The atrocities committed in Guba by the
Bolshevik and Dashnak gangs of the Baku Soviet, headed mainly by S. Shaumyan, consisting mainly of Armenians and under the command of the Dashnak Hamazasp, led to a civil war or a Soviet war. It was not the establishment of a society, but the massacre of an entire nation solely on the basis of its national and religious affiliation.

1. ARDA, f. 1061, p. 1, w 96.

\section{REFERENCES}

2. ARDA, f. 1061, p. 1, w 95.

3. ARPIIISSA, f. 276, p. 2, w 22.

4. ARPIISSA, f. 456, p. 18, w 37.

5. ARPIİSSA, f. 276, p. 2, w 22.

6. “Azerbaijan" newspaper, July 11, 1919.

7. Erogul A. Armenian Dashnak fascism and Azerbaijan, Baku : Education, 2007, 411 p.

8. "İttiha" newspaper, 1919, 6 September, 31 October.

9. Iskandarov A. Historiography of the problem of Turkish-Muslim genocide in Azerbaijan. B. : Adiloğlu, 2006,391 p.

10. Malikmammadov M. Bloody valley: Guba tragedy of 1918, B., 2009, 415 p.

11. Rustamov-Togidi S. Guba. April-May 1918. Muslim pogroms in documents. B., 2010, 552 p. 